under the presidency of Prof. E. J. Bigwood, rector of the University of Brussels. The scientific programme of the Congress will be made up of symposia, sessions for members' communications and general lectures. There will be, in all, thirty-two symposia, which will cover the following seventeen topics: organic chemistry of substances of biological interest ; chemistry and physical chemistry of proteins and polypeptides; chemistry and physical chemistry of nucleoproteins and nucleic acids; enzymology; intermediary metabolism; biological oxidations and oxidative phosphorylations ; biochemical regulations ; biochemistry of the cell ; biochemistry of muscle and the central nervous system; biochemistry of microorganisms; plant biochemistry and biochemistry of the soil ; chemical zoology; nutrition; chemical pathology; chemical pharmacology ; elinical chemistry; and industrial biochemistry. 'The two general lectures, to be given at the opening and closing sessions of the Congress respectively, will be as follows : Prof. Carl Martius (Physiological Chemical Institute of the University of Würzburg) speaking on "Thyroxin und Oxydative Phosphorylierung", and Prof. Vincent du Vigneaud (Cornell University Medical College, New York) on "The Hormones of the Posterior Pituitary". "Those intending to read papers must send in abstracts, not exceeding two hundred words, to the General Secretary of the Congress before April 1. The registration fee for the Congress is 600 Belgian francs (about $£ 4$ or 12 dollars) for active participants or 100 francs for associate members. Registration can be made through the American Express Co., Inc. (51 Cantersteen, Brussels, or any of its offices elsewhere), and should be made as soon as possible, in any event not later than May 31. All scientific communications should be addressed to the General Secretary of the Congress at 17 Place Delcour, Liège, from whom further information can be obtained.

\section{Royal Society : Officers for 1955}

THE following have been elected officers and council of the Royal Society for the ensuing year: President, Dr. E. D. Adrian; Treasurer and VicePresident, Sir Thomas Merton; Secretaries and VicePresidents, Sir Edward Salisbury and Sir David Brunt; Foreign Secretary, Sir Cyril Hinshelwood; Other Members of Council, Prof. W. Baker, Prof. F. W. R. Brambell, Prof. F. Dickens, Sir Alan Drury, Prof. J. H. Gaddum, Prof. I. Howarth, Mr. A. E. Ingham, Prof. W. B. R. King, Prof. W. H. MeCrea, Prof. K. Mather, Sir Edward Mellanby, Prof. P. B. Moon, Prof. W. H. Pearsall, Mr. J. A. Ratcliffe, Prof. J. M. Robertson and Dr. C. Sykes.

\section{Mond Nickel Fellowships, 1954}

The Mond Nickel Fellowships Committee announces the following awards for 1954 : M. Brownlee (Dorman, Long and Co., Ltd., Redcar), to study British, Continental and American hot and cold metal basic openhearth steel-making with particular reference to furnace design and construction and factors affecting ingot quality; R. D. Butler (Imperial Chemical Industries, Ltd., Liverpool), to study mineral dressing practice in Great Britain, on the Continent and in the United States and Canada, with particular reference to the design, layout and operation of small-scale mills : F. B. Peacock (Dorman, Long and Co., Ltd., Middlesbrough), to study rolling mill operation and maintenance with particular reference to soaking pits, blooming mills and the production of universal beams, structural sections and rails; A. M. Sage (British Iron and Steel Research Association, London), to study the manufacture and fabrication of structural steels in the United Kingdom, Europe, the United States and Canada.

\section{Announcements}

WE regret to announce the death of Dr. G. F. C. Searle, F.R.S., formerly University lecturer in experimental physics in the University of Cambridge, on December 16, aged ninety.

THE title of emeritus professor has been conferred by the University of Sheffield on Prof. I. C. F. Statham, who has recently retired from the chair of mining in the University (see Nature, August 7, p. 250).

The Council of the Royal Society has awarded Locke Research Fellowships to the following: M. de Burgh Daly, to work on carotid sinus reflexes and hromodynamies of the pulmonary circulation, at University College, London; J. C. F. Poole, to work on the effects of fat absorption and blood coagulation and thrombosis, at the Sir William Dunn School of Pathology, Oxford.

Mr. A. D. KNox, lecturer at the London School of Economics and Political Science, has been appointed to the University readership in economics, with special reference to the economics of underdeveloped countries, tenable at the School. The title of reader in economics in the University of London has been conferred on Dr. A. W. H. Phillips in respect of his post at the London School of Economies and Political Science.

ON the occasion of the annual general meeting of the Manchester and District Section of the Royal Institute of Chemistry, an exhibition of chemical laboratory apparatus, instruments and techniques will be held in the Manchester College of Technology and will be open to the public on January 5 (2-8 p.m.) and January 6 (10 a.m.-8 p.m.). Special emphasis will be laid this year on distillation and fractionation equipment.

A cOMPLete and informative catalogue of recent publications of the Institute of Physics, covering the "Physics in Industry" series, the Institute's two monthly journals and their supplements, the "Monographs for Students" series and numerous reports and pamphlets, together with various books published for the Institute by Edward Arnold (Publishers), Ltd., is now available and can be obtained free from the offices of the Institute, 47 Belgrave Square, London, S.W.1.

Dr. Maurice CooK, joint marnaging director of the Metals Division, Imperial Chemical Industries, Ltd., has been elected chairman of the British NonFerrous Metals Research Association in succession to the Hon. R. M. Preston, who retires from office at the end of this year. In addition to his many contributions to science and technology in industry, Dr. Cook is distinguished for his services to the metallurgical profession. He is a past president of the Institution of Metallurgists and senior vice-president and president-elect of the Institute of Metals, and, among his many activities connected with the Research Association, he has been chairman of the Research Board since 1950. 